Article

\title{
Dung Beetle Assemblages Attracted to Cow and Horse Dung: The Importance of Mouthpart Traits, Body Size, and Nesting Behavior in the Community Assembly Process
}

\author{
Mattia Tonelli ${ }^{1,2, * \mathbb{D}}$, Victoria C. Giménez Gómez ${ }^{3}$, José R. Verdú ${ }^{2}$, Fernando Casanoves ${ }^{4}$ (D) and Mario Zunino ${ }^{5}$ \\ 1 Department of Pure and Applied Science (DiSPeA), University of Urbino “Carlo Bo", 61029 Urbino, Italy \\ 2 I.U.I CIBIO (Centro Iberoamericano de la Biodiversidad), Universidad de Alicante, San Vicente del Raspeig, \\ 03690 Alicante, Spain; jr.verdu@ua.es \\ 3 Instituto de Biología Subtropical, Universidad Nacional de Misiones-CONICET, 3370 Puerto Iguazú, \\ Argentina; gimenezgomezvictoria@conicet.gov.ar \\ 4 CATIE, Centro Agronómico Tropical de Investigación y Enseñanza, 30501 Turrialba, Costa Rica; \\ casanoves@catie.ac.cr \\ 5 Asti Academic Centre for Advanced Studies, School of Biodiversity, 14100 Asti, Italy; mario.zunino@uniurb.it \\ * Correspondence: mattia.tonelli@uniurb.it
}

\section{check for}

updates

Citation: Tonelli, M.; Giménez Gómez, V.C.; Verdú, J.R.; Casanoves, F.; Zunino, M. Dung Beetle Assemblages Attracted to Cow and Horse Dung: The Importance of Mouthpart Traits, Body Size, and Nesting Behavior in the Community Assembly Process. Life 2021, 11, 873. https://doi.org/10.3390/life11090873

Academic Editors: Anita Giglio and Federica Talarico

Received: 30 June 2021

Accepted: 17 August 2021

Published: 25 August 2021

Publisher's Note: MDPI stays neutral with regard to jurisdictional claims in published maps and institutional affiliations.

Copyright: (c) 2021 by the authors. Licensee MDPI, Basel, Switzerland. This article is an open access article distributed under the terms and conditions of the Creative Commons Attribution (CC BY) license (https:/ / creativecommons.org/licenses/by/ $4.0 /)$.

\begin{abstract}
Dung beetles use excrement for feeding and reproductive purposes. Although they use a range of dung types, there have been several reports of dung beetles showing a preference for certain feces. However, exactly what determines dung preference in dung beetles remains controversial. In the present study, we investigated differences in dung beetle communities attracted to horse or cow dung from a functional diversity standpoint. Specifically, by examining 18 functional traits, we sought to understand if the dung beetle assembly process is mediated by particular traits in different dung types. Species specific dung preferences were recorded for eight species, two of which prefer horse dung and six of which prefer cow dung. Significant differences were found between the functional traits of the mouthparts of the dung beetles attracted to horse dung and those that were attracted to cow dung. Specifically, zygum development and the percentage of the molar area and the conjunctive area differed between horse and cow dung colonizing beetles. We propose that the quantitative differences in the mouthpart traits of the species attracted to horse and cow dung respectively could be related to the differential capacity of the beetles to filtrate and concentrate small particles from the dung. Hence, the dung preference of dung beetles could be related to their ability to exploit a specific dung type, which varies according to their mouthpart traits. Moreover, we found that larger and nester beetles preferred cow dung, whereas smaller and non-nester beetles preferred horse dung. This finding could be related to the tradeoff between fitness and parental investments, and to the suitability of the trophic resource according to the season and species phenology.
\end{abstract}

Keywords: trophic preference; environmental filter; functional diversity; functional traits; niche partitioning; Scarabaeoidea

\section{Introduction}

Dung beetles (Scarabaeidae: Scarabaeinae, Aphodiinae; Geotrupidae) are distributed in all biogeographic regions and include more than 8000 species [1]. They are mainly coprophagous, a feeding habit which arose from saprophagy in the Cretaceous, leading to a species radiation during mammal diversification in the Cenozoic [2,3]. After the extinction of megafauna, in some places (e.g., Italy, Spain), the feces of domestic livestock became the beetles' main trophic resource in human-dominated landscapes [4]. In other places (e.g., tropical and subtropical habitats), however, dung beetles became more generalist species associated with the greater diversity and abundance of other types of resource, such as omnivorous dung, vertebrate and invertebrate carrion, fungi, and fruits $[5,6]$. 
In places where dung is the main source of food, dung beetles use this resource throughout their ontogenetic development, from larval to adult stages [7]. Due to the scarcity of dung in many ecosystems, its scattered occurrence and short existence, dung beetles show an opportunistic and generalized use of a broad range of dung types [8-10], and species that are linked exclusively to one kind of dung are very rare [11-15]. Nonetheless, the trophic predilection of dung beetles for certain dung types has often been reported [5,16-24], although this preference seems to vary geographically, suggesting that it may not depend on a fixed species trait [25].

Dung is a transient resource with a patchy temporal and spatial distribution $[7,8]$. Despite its ephemerality, dung is very rich in nutrients, such as minerals, vitamins, carbohydrates, nitrogen, amino acids, and lipids [24,26,27]. Excrement from different species differs markedly in terms of its chemical and physical characteristics [27,28]. Dung from different feeding guilds of vertebrates (i.e., carnivores, omnivores, and herbivores) varies in terms of its composition and proportion of nutrients. Moreover, variations are also found in different species within the same feeding guild [24,27]. For example, the excrement of horses and cows, monogastric and ruminant herbivores, respectively, differs in terms of its nutrient and fiber content, moisture, and volatile organic compounds (VOCs), [24,27,29-31]. Different types of feces emit VOCs that are detected by dung beetles through olfactory sensilla on their antennae [32]. Whereas some VOCs are found in all dung types, others seem specific to particular kinds of dung $[29,31]$ and could be used by dung beetles as semio-chemical cues for detecting and selecting their preferred excrement $[30,33]$.

Trophic preferences have important consequences for dung beetles because feeding and nesting with different dung types influence their fitness $[17,34,35]$, which in turn can lead to important changes in community structures and compositions over time [36-39]. What determines the dung preference of dung beetles is, however, a controversial topic. Gittings \& Giller [40] found that dung beetle preference is linked to species oviposition behavior. Another factor that could have an effect on preference is the capacity of the beetle to physically make use of the dung. This capacity depends mainly on the moisture and fiber content of the dung; hence, we have the distinction between 'soft-diet' and 'hard-diet' consumers [41-44]. The quality of the dung may also have an impact, but findings related to this aspect are conflicting [24,40].

Although several studies have investigated dung beetle biodiversity and species preference for different dung types, to the best of our knowledge, none of these studies has performed a comprehensive analysis using a functional diversity methodology. This approach improves our ecological understanding by focusing on characteristics that define how organisms interact with their physical, chemical, and biological environments [45]. Such an approach could in fact shed light on community assembly processes by examining trait patterns [46,47], where traits are defined as "morphological, biochemical, physiological, structural, phenological, or behavioral characteristics of organisms that influence how they respond to the environment and/or their effects on ecosystem properties" [48]. Thus, the functional diversity approach could provide an additional and complementary source of evidence in addition to taxonomic composition [49,50].

Therefore, the purpose of this study was to examine dung beetle assemblages colonizing cow or horse dung in order to determine if differences exist between the two assemblages in terms of species trophic preference and functional traits. We sought to answer two main questions: (i) Are there species which have a preference for cow or horse dung? (ii) Are there some traits linked to a specific dung type? To answer these questions, we focused on multiple $(\mathrm{N}=18)$ species traits related to body morphology, mouthpart morphology, and behavior, seeking to ascertain if the assembly process in different dung types is mediated by these particular traits. 


\section{Materials and Methods}

\subsection{Study Area and Sampling Design to Estimate Trophic Preferences}

The study area is located in the sub-mountain pastures of the central Apennine Range (Pesaro-Urbino province, Italy) with an altitudinal range between $500-900 \mathrm{~m}$ a.s.l. The climate of the area is temperate. Within the province, we selected five pastures with an extension of between about 20 and 60 hectares (Isola del Piano, Catria, Nerone, Calamello, Pietralata) (see Tonelli et al., [38,51] for further details on the study area and pastures), and within each pasture we selected three sampling sites, separated by at least $500 \mathrm{~m}$ to guarantee spatial independence [52,53]. In each sampling site, we placed square with four standardized pitfall traps (CSR model in Lobo et al., [54]) positioned at the corners, separated by about $50 \mathrm{~m}$ (four traps $\times$ three sampling sites $\times$ five pastures $=$ a total of 60 traps). Two of the traps were baited with cow dung $\left(500 \mathrm{~cm}^{3}\right)$, while the other two were baited with horse dung $\left(500 \mathrm{~cm}^{3}\right)$. The dung was frozen to kill any dung beetles, predators or Diptera larvae that may have altered the results. The data of the two pitfall traps baited with the same type of dung at each sampling site were coupled; hence, there were a total of 30 sampling points (two dung type $\times$ three sampling sites $\times$ five pastures). Traps were exposed for 48 h every 15 days from June to November 2013 and in May and June 2014. The data of each sampling day were added together to obtain the cumulative abundance and richness of the assemblages. The dung that was used to bait the traps was ivermectin free because this veterinary medical product could alter dung attraction [55].

\subsection{Functional Traits}

In total we measured 18 functional traits: 11 morphological (seven associated with the body and four with the mouthpart), and seven behavioral. All traits are associated directly or indirectly with ecological functions. We present a summary table (Table 1) with the potential biological and functional importance of each trait. For further details on the measurement protocols of each trait see Supplementary Materials Files S1 and S2, and Tonelli et al. [56].

Table 1. Summary of measured functional traits and their link to ecological functions (See Supplementary Materials Files S1 and S2 for further details). BM = Body Morphology; MM = Mouthpart Morphology; E = Ethological; Quan = Quantitative; Qual = Qualitative.

\begin{tabular}{|c|c|c|c|}
\hline Trait & Trait Type & Data Type & Functional Link \\
\hline Fresh body mass & $\mathrm{BM}$ & Quan & $\begin{array}{c}\text { Resource use } \\
\text { Metabolic rate } \\
\text { Thermoregulatory pattern } \\
\text { Competition }\end{array}$ \\
\hline Sphericity & $\mathrm{BM}$ & Quan & Resource use \\
\hline Head area/Total area Ratio & $\mathrm{BM}$ & Quan & Resource use \\
\hline Hind tibiae length & $\mathrm{BM}$ & Quan & Resource use \\
\hline Metamesosternal area & $\mathrm{BM}$ & Quan & Dispersal capability \\
\hline Abdomen length & $\mathrm{BM}$ & Quan & Resource use \\
\hline Wing load & $\mathrm{BM}$ & Quan & $\begin{array}{c}\text { Dispersal capability } \\
\text { Foraging strategy } \\
\text { Habitat use } \\
\text { Thermoregulatory pattern }\end{array}$ \\
\hline Number of teeth in the mandibles profile & MM & Quan & Resource use \\
\hline Conjunctive/total mandible area ratio & MM & Quan & Resource use \\
\hline
\end{tabular}


Table 1. Cont.

\begin{tabular}{|c|c|c|c|}
\hline Trait & Trait Type & Data Type & Functional Link \\
\hline $\begin{array}{l}\text { Percentage of filtering/masticator area of } \\
\text { mandibular molars }\end{array}$ & $\mathrm{MM}$ & Quan & Resource use \\
\hline Zygum & MM & Qual & Resource use \\
\hline Trophic diversity & $\mathrm{E}$ & Quan & Resource use \\
\hline Nest type & $\mathrm{E}$ & Qual & $\begin{array}{l}\text { Resource use } \\
\text { Competition } \\
\text { Habitat use }\end{array}$ \\
\hline Nest depth & $\mathrm{E}$ & Qual & $\begin{array}{l}\text { Resource use } \\
\text { Competition } \\
\text { Habitat use }\end{array}$ \\
\hline Horizontal nest distance & $\mathrm{E}$ & Qual & $\begin{array}{l}\text { Resource use } \\
\text { Competition } \\
\text { Habitat use }\end{array}$ \\
\hline Nesting patterns & $\mathrm{E}$ & Qual & $\begin{array}{l}\text { Resource use } \\
\text { Competition } \\
\text { Habitat use }\end{array}$ \\
\hline Daily activity & $\mathrm{E}$ & Qual & $\begin{array}{l}\text { Resource use } \\
\text { Competition } \\
\text { Habitat use }\end{array}$ \\
\hline Phenology & $\mathrm{E}$ & Qual & $\begin{array}{l}\text { Resource use } \\
\text { Competition } \\
\text { Habitat use }\end{array}$ \\
\hline
\end{tabular}

\subsection{Data Analysis}

\subsubsection{Trophic Preferences}

Dung beetle preference was analyzed using the Indicator Value Method (IndVal) [57]. This method measures species specificity and fidelity to an ecological status (in our case, fidelity to a dung type). Species with a significant IndVal $(p<0.05)$ were considered to prefer that type of excrement. The analysis was performed using PC-ORD 5 [58].

\subsubsection{Functional Diversity}

Taking into consideration all measured functional traits and all species, we investigated the effect of dung type on functional diversity using single trait indices: CWM, FDvar, and FRO. CWM (community weighted mean) represents the expected functional value of one trait in a random community sample. It is the community mean of a trait weighted by the relative abundance of the taxa [59]. FDvar (functional divergence) can be defined as the variance of a trait in a community, whose squared residuals are weighted by the abundance of the species [60]. It is constrained between $0-1$; high values of functional divergence are related to a high degree of niche differentiation, whereas low values indicate a low level of niche differentiation [61]. FRO (functional regularity) is the regularity or evenness of the trait values and abundance in the observed range [62]. It is constrained between 0-1, showing higher values when each species has the same distance from its neighbors and each species is present in the same abundance [62].

The functional diversity indices were calculated using FDiversity software [63]. Dummy variables were created for each category of categorical traits. We used linear mixed models (LMM) to evaluate dung type effect (cow vs. horse) on functional diversity indices. Sampling sites were added as random factors in the LMM procedure in order to avoid any potential effect related to differences in the pastures where the data were collected [64]. When the null hypothesis was rejected, we used Fisher LSD for mean comparison $(p<0.05)$. We evaluated the assumptions of normality and homogeneity of variances using graphical analyses of residuals. Statistical analyses were performed with InfoStat version 2020 [65]. 


\section{Results}

\subsection{Trophic Preferences}

In total, we collected 156,936 individuals belonging to 58 species. In the horse dung, 90,480 individuals belonging to 50 species were collected (three exclusive species: Amidorus thermicola (Sturm, 1800), Euorodalus paracoenosus (Balthasar \& Hrubant, 1960), Limarus zenkeri (Germar, 1813)), whereas in the cow dung, 66,456 individuals belonging to 55 species were collected (eight exclusive species: Melinopterus stolzi (Reitter, 1906), Nialus varians (Duftschmid, 1805), Calamosternus mayeri (Pilleri, 1953), Bodiloides ictericus (Laicharting, 1781), Biralus mahunkaorum (Ádám, 1983), Acrossus rufipes (Linnaeus, 1758), Agrilinus constans (Duftschmid, 1805), Planolinus fasciatus (Olivier, 1789)) (Table 2). Eight species with a significant trophic preference (IndVal: $p<0.05$ ) were identified: two for horse dung and six for cow dung (Table 3).

Table 2. Raw data on total dung beetle species and individuals collected in horse and cow dung.

\begin{tabular}{|c|c|c|c|c|c|c|}
\hline Family & Subfamily & Tribe & Species & Horse & Cow & Total \\
\hline Scarabaeidae & Aphodiinae & Aphodiini & Acanthobodilus immundus (Creutzer, 1799) & 6 & 17 & 23 \\
\hline Scarabaeidae & Aphodiinae & Aphodiini & Acrossus luridus (Fabricius, 1775) & 66 & 163 & 229 \\
\hline Scarabaeidae & Aphodiinae & Aphodiini & Acrossus rufipes (Linnaeus, 1758) & 0 & 4 & 4 \\
\hline Scarabaeidae & Aphodiinae & Aphodiini & Agrilinus constans (Duftschmid, 1805) & 0 & 1 & 1 \\
\hline Scarabaeidae & Aphodiinae & Aphodiini & Agrilinus convexus (Erichson, 1848) & 5 & 18 & 23 \\
\hline Scarabaeidae & Aphodiinae & Aphodiini & Amidorus thermicola (Sturm, 1800) & 2 & 0 & 2 \\
\hline Scarabaeidae & Aphodiinae & Aphodiini & Aphodius coniugatus (Panzer, 1795) & 1 & 10 & 11 \\
\hline Scarabaeidae & Aphodiinae & Aphodiini & Aphodius fimetarius (Linnaeus, 1758) & 44 & 114 & 158 \\
\hline Scarabaeidae & Aphodiinae & Aphodiini & Aphodius foetidus (Herbst, 1783) & 4 & 7 & 11 \\
\hline Scarabaeidae & Aphodiinae & Aphodiini & Biralus mahunkaorum (Ádám, 1983) & 0 & 1 & 1 \\
\hline Scarabaeidae & Aphodiinae & Aphodiini & Bodilopsis rufa (Moll, 1782) & 21 & 808 & 829 \\
\hline Scarabaeidae & Aphodiinae & Aphodiini & Bodiloides ictericus (Laicharting, 1781) & 0 & 11 & 11 \\
\hline Scarabaeidae & Aphodiinae & Aphodiini & Calamosternus granarius (Linnaeus, 1767) & 20 & 3 & 23 \\
\hline Scarabaeidae & Aphodiinae & Aphodiini & Calamosternus mayeri (Pilleri, 1953) & 0 & 1 & 1 \\
\hline Scarabaeidae & Aphodiinae & Aphodiini & Chilothorax conspurcatus (Linnaeus, 1758) & 778 & 3 & 781 \\
\hline Scarabaeidae & Aphodiinae & Aphodiini & Chilothorax lineolatus (Illiger, 1803) & 2 & 1 & 3 \\
\hline Scarabaeidae & Aphodiinae & Aphodiini & Chilothorax paykulli (Bedel, 1907) & 48 & 5 & 53 \\
\hline Scarabaeidae & Aphodiinae & Aphodiini & Colobopterus erraticus (Linnaeus, 1758) & 401 & 2612 & 3013 \\
\hline Scarabaeidae & Aphodiinae & Aphodiini & Coprimorphus scrutator (Herbst, 1789) & 45 & 134 & 179 \\
\hline Scarabaeidae & Aphodiinae & Aphodiini & Esymus merdarius (Fabricius, 1775) & 57 & 50 & 107 \\
\hline Scarabaeidae & Aphodiinae & Aphodiini & Esymus pusillus (Herbst, 1789) & 6 & 31 & 37 \\
\hline Scarabaeidae & Aphodiinae & Aphodiini & $\begin{array}{c}\text { Euorodalus paracoenosus (Balthasar \& } \\
\text { Hrubant, 1960) }\end{array}$ & 2 & 0 & 2 \\
\hline Scarabaeidae & Aphodiinae & Aphodiini & Labarrus lividus (Olivier, 1789) & 663 & 8 & 671 \\
\hline Scarabaeidae & Aphodiinae & Aphodiini & Limarus zenkeri (Germar, 1813) & 2 & 0 & 2 \\
\hline Scarabaeidae & Aphodiinae & Aphodiini & Loraphodius suarius (Faldermann, 1836) & 33 & 19 & 52 \\
\hline Scarabaeidae & Aphodiinae & Aphodiini & Melinopterus consputus (Creutzer, 1799) & 61,128 & 40,406 & 101,534 \\
\hline Scarabaeidae & Aphodiinae & Aphodiini & Melinopterus prodromus (Brahm, 1790) & 6859 & 531 & 7390 \\
\hline Scarabaeidae & Aphodiinae & Aphodiini & Melinopterus reyi (Reitter, 1892) & 12 & 4 & 16 \\
\hline Scarabaeidae & Aphodiinae & Aphodiini & Melinopterus stolzi (Reitter, 1906) & 0 & 2 & 2 \\
\hline Scarabaeidae & Aphodiinae & Aphodiini & Nialus varians (Duftschmid, 1805) & 0 & 9 & 9 \\
\hline Scarabaeidae & Aphodiinae & Aphodiini & Nimbus contaminatus (Herbst, 1783) & 435 & 371 & 806 \\
\hline Scarabaeidae & Aphodiinae & Aphodiini & Nimbus johnsoni (Baraud, 1976) & 12 & 9 & 21 \\
\hline Scarabaeidae & Aphodiinae & Aphodiini & Nimbus obliteratus (Panzer, 1823) & 2175 & 829 & 3004 \\
\hline Scarabaeidae & Aphodiinae & Aphodiini & Otophorus haemorroidalis (Linnaeus, 1758) & 9 & 63 & 72 \\
\hline Scarabaeidae & Aphodiinae & Aphodiini & Phalacronothus biguttatus (Germar, 1824) & 2 & 4 & 6 \\
\hline Scarabaeidae & Aphodiinae & Aphodiini & Planolinus fasciatus (Olivier, 1789) & 0 & 2 & 2 \\
\hline Scarabaeidae & Aphodiinae & Aphodiini & Sigorus porcus (Fabricius, 1792) & 216 & 179 & 395 \\
\hline Scarabaeidae & Aphodiinae & Aphodiini & Teuchestes fossor (Linnaeus, 1758) & 1 & 11 & 12 \\
\hline Scarabaeidae & Aphodiinae & Aphodiini & Trichonotulus scrofa (Fabricius, 1787) & 45 & 202 & 247 \\
\hline Scarabaeidae & Scarabaeinae & Onitini & Bubas bison (Linnaeus, 1767) & 30 & 76 & 106 \\
\hline
\end{tabular}


Table 2. Cont.

\begin{tabular}{|c|c|c|c|c|c|c|}
\hline Family & Subfamily & Tribe & Species & Horse & Cow & Total \\
\hline Scarabaeidae & Scarabaeinae & Coprini & Copris lunaris (Linnaeus, 1758) & 11 & 12 & 23 \\
\hline Scarabaeidae & Scarabaeinae & Oniticellini & Euoniticellus fulvus (Goeze, 1777) & 6129 & 4130 & 10,259 \\
\hline Scarabaeidae & Scarabaeinae & Onthophagini & Caccobius schreberi (Linnaeus, 1767) & 14 & 16 & 30 \\
\hline Scarabaeidae & Scarabaeinae & Onthophagini & Onthophagus coenobita (Herbst, 1783) & 80 & 126 & 206 \\
\hline Scarabaeidae & Scarabaeinae & Onthophagini & Onthophagus fracticornis (Preyssler, 1790) & 3935 & 6124 & 10,059 \\
\hline Scarabaeidae & Scarabaeinae & Onthophagini & Onthophagus grossepunctatus Reitter, 1905 & 46 & 108 & 154 \\
\hline Scarabaeidae & Scarabaeinae & Onthophagini & Onthophagus illyricus (Scopoli, 1763) & 1 & 1 & 2 \\
\hline Scarabaeidae & Scarabaeinae & Onthophagini & Onthophagus joannae Goljan, 1953 & 297 & 560 & 857 \\
\hline Scarabaeidae & Scarabaeinae & Onthophagini & Onthophagus lemur (Fabricius, 1781) & 194 & 493 & 687 \\
\hline Scarabaeidae & Scarabaeinae & Onthophagini & Onthophagus medius (Kugelann, 1792) & 5273 & 5601 & 10,874 \\
\hline Scarabaeidae & Scarabaeinae & Onthophagini & Onthophagus opacicollis Reitter, 1892 & 11 & 27 & 38 \\
\hline Scarabaeidae & Scarabaeinae & Onthophagini & Onthophagus ruficapillus Brullé, 1832 & 41 & 166 & 207 \\
\hline Scarabaeidae & Scarabaeinae & Onthophagini & Onthophagus taurus (Schreber, 1759) & 365 & 506 & 871 \\
\hline Scarabaeidae & Scarabaeinae & Onthophagini & Onthophagus verticicornis (Laicharting, 1781) & 564 & 761 & 1325 \\
\hline Scarabaeidae & Scarabaeinae & Sisyphini & Sisyphus schaefferi (Linnaeus, 1758) & 180 & 781 & 961 \\
\hline Geotrupidae & Geotrupinae & Geotrupini & Geotrupes spiniger Marsham, 1802 & 91 & 174 & 265 \\
\hline Geotrupidae & Geotrupinae & Geotrupini & Sericotrupes niger (Marsham, 1802) & 115 & 145 & 260 \\
\hline \multirow[t]{3}{*}{ Geotrupidae } & Geotrupinae & Geotrupini & $\begin{array}{l}\text { Trypocopris vernalis apenninicus (Mariani, } \\
1958 \text { ) }\end{array}$ & 3 & 6 & 9 \\
\hline & & & Total species (S) & 50 & 55 & 58 \\
\hline & & & Total individuals (N) & 90,480 & 66,456 & 156,936 \\
\hline
\end{tabular}

Table 3. Dung beetle species that have a trophic preference for cow or horse dung. Numbers represent statistically significant IndVal values $(p<0.05)$.

\begin{tabular}{ccc}
\hline Indicator Species & Cow & Horse \\
\hline Aphodius coniugatus (Panzer, 1795) & 42.4 & \\
Aphodius fimetarius (Linnaeus, 1758) & 67.3 & \\
Bodilopsis rufa (Moll, 1782) & 84.5 & \\
Colobopterus erraticus (Linnaeus, 1758) & 86.7 & \\
Esymus pusillus (Herbst, 1789) & 61.4 & 59.8 \\
Geotrupes spiniger Marsham, 1802 & 65.7 & 92.2 \\
Chilothorax conspurcatus (Linnaeus, 1758) & & \\
Labarrus lividus (Olivier, 1789) & & \\
\hline
\end{tabular}

\subsection{Functional Diversity}

The CWMs showed differences in 10 functional traits $(p<0.05)$ : four related to body morphology (fresh body mass, hind tibiae length, abdomen length, and wing load), one related to mouthpart morphology (zygum development) and five to ethological traits (nesting pattern, nest type, nest depth, horizontal nest distance, and phenology). Specifically, fresh body mass, hind tibiae length, abdomen length, and wing load showed higher values in cow dung. Regarding mouthpart morphology, we found that the CWM of zygum development was higher in horse dung. As regards ethological traits, we found that the CWM of nesters (telecoprid and paracoprid with a horizontal and vertical relocation of trophic source) was higher in cow dung, whereas non-nesters that do not relocate dung showed a higher CWM in horse dung. Finally, phenology varied significantly between dung type, with a higher CWM in species that are active all year or in summer-autumn seasons in the cow dung, while the CWM of species actives in autumn, winter and spring was higher in the horse dung.

The FRO of the percentage of molar filtering area was higher in horse dung $(p<0.05)$. The FDvar of the percentage of the conjunctive area and the phenology of species actives throughout the year was higher in cow dung $(p<0.05)$ (Table 4$)$. 
Table 4. Traits that showed significant differences between dung type (cow and horse) according to the results of CWM, FDvar and FRO indices. The X means a higher significant $(p<0.05)$ value of the index for each trait. More details on these results can be found in the Supplementary Material File S3.

\begin{tabular}{|c|c|c|c|c|c|c|c|}
\hline \multirow{2}{*}{ Trait Type } & \multirow{2}{*}{ Trait Name } & \multicolumn{2}{|c|}{ CWM } & \multicolumn{2}{|c|}{ FDvar } & \multicolumn{2}{|c|}{ FRO } \\
\hline & & Cow & Horse & Cow & Horse & Cow & Horse \\
\hline \multirow{4}{*}{ Body Morphology } & Fresh body mass & $X$ & & & & & \\
\hline & Hind tibiae length & $x$ & & & & & \\
\hline & Abdomen length & $X$ & & & & & \\
\hline & Wing load & $X$ & & & & & \\
\hline \multirow{4}{*}{$\begin{array}{l}\text { Mouthpart } \\
\text { Morphology }\end{array}$} & Conjunctive/total mandible area ratio & & & $x$ & & & \\
\hline & Percentage of filtering area of mandibular molars & & & & & & $X$ \\
\hline & Zygum developed & & $x$ & & & & \\
\hline & Zygum underdeveloped & $X$ & & & & & \\
\hline \multirow{14}{*}{ Ethological } & Nest type 0 (non-nester) & & $x$ & & & & \\
\hline & $\begin{array}{l}\text { Nest type } 3 \text { (Nest composed of a single brood } \\
\text { mass located underground in a simple nest) }\end{array}$ & $x$ & & & & & \\
\hline & $\begin{array}{l}\text { Nest type } 7 \text { (Nest composed of a single brood ball } \\
\text { located underground in a simple nest) }\end{array}$ & $X$ & & & & & \\
\hline & Nest depth 0 (within excrement) & & $x$ & & & & \\
\hline & Horizontal nest distance 0 (within food source) & & $x$ & & & & \\
\hline & $\begin{array}{l}\text { Horizontal nest distance } 1 \text { (starting within food } \\
\text { source but with a horizontal extension) }\end{array}$ & $x$ & & & & & \\
\hline & $\begin{array}{l}\text { Horizontal nest distance } 3 \text { (a great distance out } \\
\text { from the food source) }\end{array}$ & $x$ & & & & & \\
\hline & $\begin{array}{l}\text { Nesting patterns } 2 \text { (Telecoprid } \\
\text { medium-little sized) }\end{array}$ & $x$ & & & & & \\
\hline & $\begin{array}{c}\text { Nesting patterns } 5 \text { (Paracoprid with large } \\
\text { body size) }\end{array}$ & $x$ & & & & & \\
\hline & $\begin{array}{l}\text { Nesting patterns } 8 \text { (Paracoprid with small body } \\
\text { size burying dung slowly and at shallow depth } \\
\text { without well-developed brood mass) }\end{array}$ & $x$ & & & & & \\
\hline & Nesting patterns 11 (non-nester) & & $\mathrm{X}$ & & & & \\
\hline & Phenology 1 (Autumn, winter and spring) & & $x$ & & & & \\
\hline & Phenology 8 (Summer and autumn) & $x$ & & & & & \\
\hline & Phenology 14 (All year) & $x$ & & $x$ & & & \\
\hline
\end{tabular}

\section{Discussion}

In the present study we investigated the attractiveness of horse and cow dung to dung beetles using a comprehensive range of functional diversity indices and functional traits. Our investigation showed the presence of dung beetle species with a trophic preference for horse or cow dung. We also found quantitative differences in some mouthpart traits (zygum, conjunctive and molar filtering area) between dung beetles attracted to horse dung and those attracted to cow dung. Furthermore, our results suggest that larger and nester beetles prefer cow dung, whereas smaller and non-nester beetles prefer horse dung. Finally, it was found that phenology could be important to dung beetle trophic selection. 


\subsection{Trophic Preferences}

Our results regarding trophic preferences are consistent with those of Barbero et al. [25] and Dormont et al. $[18,29,66]$. Previous studies conducted in Europe have found all the species examined in this study in a great variety of dung types [67,68]. Nevertheless, comparing our results with these studies, which explicitly evaluated trophic preference, we found that Aphodius fimetarius (Linnaeus, 1758) and Colobopterus erraticus (Linnaeus, 1758 ) were generally more attracted to cow dung $[18,66]$. For the other species (Aphodius coniugatus (Panzer, 1795), Bodilopsis rufa (Moll, 1782), Esymus pusillus (Herbst, 1789), Geotrupes spiniger Marsham, 1802, Chilothorax conspurcatus (Linnaeus, 1758) and Labarrus lividus (Olivier, 1789)), a trophic preference for cow or horse dung was recorded for the first time. Hence, if this feeding predilection is stable through the species range, it should be investigated in other regions [25]. We also found some species exclusively in horse or cow dung, but their low abundance does not allow us to draw firm conclusions (Table 2).

\subsection{Mouthparts}

Significant differences in the mouthpart traits of the dung beetles attracted to cow dung and those attracted to horse dung were found (Figure 1). Specifically, the zygum, conjunctive and molar area development seems to play an important role during the community assembly process in these two types of dung. The zygum is the proximal part of the epipharynx covered by setae. Its development varies according to the species $[69,70]$. The conjunctive is a structure whose surface consists of lamellae and it is inserted between the distal and molar lobe of the mandibles [71]. The molar surface consists of tightly packed transverse ridges with numerous pores that connect the molar surface with a system of deeper channels [71,72]. The specific function of these traits is not yet totally clear [71], but their variability seems to be correlated with the type of dung that the beetle feeds on. Indeed, hard and soft feeders show different mouthpart features [41-44,69,71]. For example, the zygum is more developed in hard dry pellet feeders [69], whereas the development of the conjunctive area is greatly reduced. On the other hand, hard feeders show extensive development of the anterior part of the molar area [71]. In any case, all of these studies draw a distinction between hard feeders and soft feeders based on a qualitative descriptive evaluation of the morphology of their mouthparts.

The quantitative differences between the mouthpart traits of the species attracted to horse and those attracted to cow dung could thus be related to their differential capacity to filtrate and concentrate small particles from the dung. The greater development of the zygum in dung beetles attracted to horse dung and the reduced variation found in the conjunctive and zygum of these beetles could be associated with the higher overall fiber content and larger fibers found in horse excrement. Horse dung could thus influence the dung beetle community species selection based on these mouthpart features, which may be related to the elimination of coarse fibers. We also found particular mouthpart features associated with cow dung, namely the ratio between the filtering area and the total area of the molar lobes, which showed a diminished level of functional regularity. Hence, we propose that this trait could be linked to the process of concentrating the small particles in cow dung, which has a higher moisture content.

Horse and cow dung differ in terms of their physical and chemical features [27,29]. One of the most important differences lies in their relative fiber content. Horse dung contains more overall fiber and the fibers themselves tend to be of a larger size [27]. Moreover, horse dung has a lower moisture content [24]. Holter [73] proposed that dung beetles collect dung with their maxillary palps; the large particles are subsequently brushed out by filtration setae on the mouthparts, and the remaining paste is then squeezed by the molar lobes while superfluous liquid is led away from the pharynx through the filtration channels. This process concentrates the remaining small particles, which are then ingested [74]. Hence, there is no evidence that dung beetle mouthparts are involved in the trituration of large particles, and their role seems limited to the elimination of coarse fibers and the 
concentration of small particles from the aqueous medium. To our knowledge, our study is the first attempt to study the influence of mouthpart traits from a quantitative standpoint.

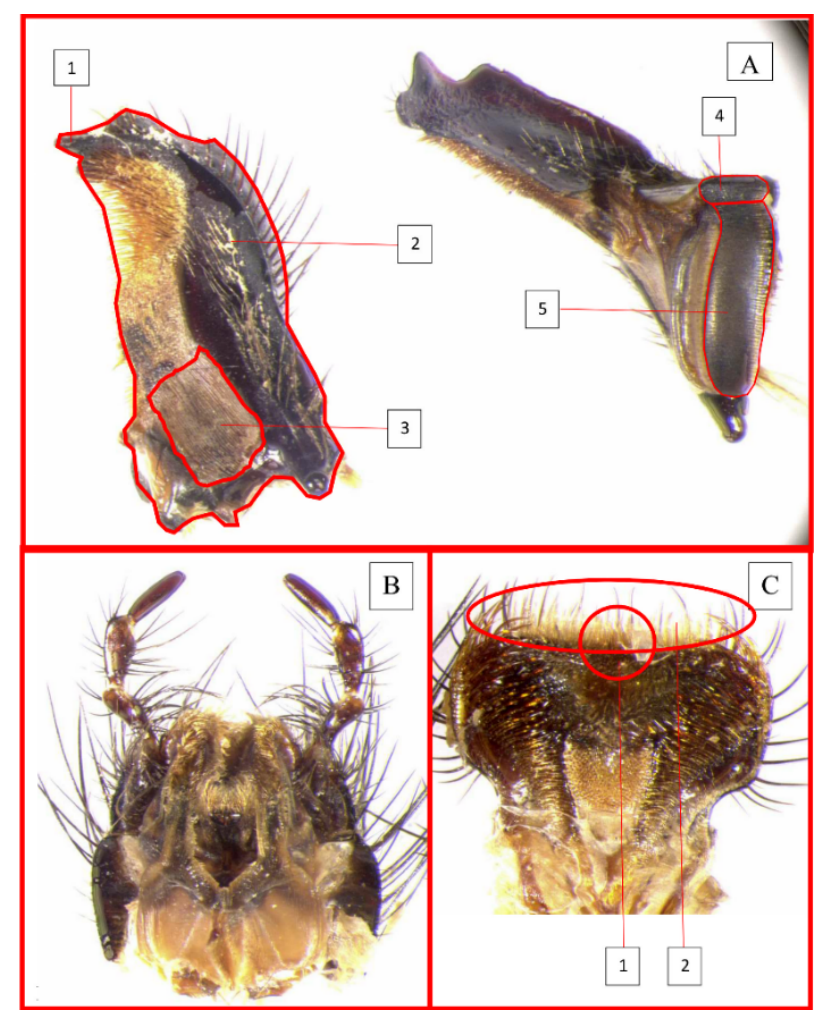

Figure 1. Morphological traits of mouthparts. Example from Geotrupes spiniger (Marsham, 1802). (A) Mandible and molar area: (1) sclerotized area of the mandible profile (incisor lobo with one tooth); (2) total mandible area; (3) conjunctive; (4) masticator area of the mandibular molar; (5) filter area of the mandibular molar. (B) Hypopharynx; (C) Epipharynx: (1) Zygum; (2) Acropariae.

\subsection{Body Size and Nesting Behavior}

Our results suggest that larger and nester beetles prefer cow dung, whereas smaller and non-nester beetles prefer horse dung. Body size is one of the most important dung beetle traits which is very sensitive to changes in trophic availability and quality [38]. Food quality determines adult dung beetle body size and influences several reproductive outputs $[34,35,75]$. Larger dung beetles need more dung for nesting, but this necessity is plastic and the amount of dung that is needed may vary according to dung quality and dung type $[35,76]$. Our results suggest that cow dung could be more suitable for larger dung beetles and can probably maximize their fitness. This result, however, is not in agreement with those reported by other authors who found an optimal investment strategy in dung beetles colonizing horse dung. For example, Hunt \& Simmons [34] found that females of the Onthophagus taurus need about $20 \%$ less dung when provisioning with horse dung, and hence received greater fitness returns per unit of investment and experienced lower provisioning costs in terms of the minimum amount of dung required to produce a surviving offspring than females provisioning with cow dung. Likewise, Moczek [75] observed that almost twice the amount of cow dung was required to yield the body size obtained with half the amount of horse dung. These investigations attribute their findings to the higher quality value of horse dung. However, dung quality can be related to the diet of the animals, showing spatiotemporal variation with seasonal consequences for the trophic preferences and reproductive outputs of dung beetles [77], which could account for the difference in our results.

Another interesting result regards dung beetle nesting behavior. We found that nester species, such as paracoprids and telecoprids, which show relocation behavior [78], prefer 
cow dung. On the contrary, non-nester species, which lay eggs directly in the dung pat where the entire development takes place, clearly prefer horse dung [79]. This interesting finding is counterintuitive because, generally, non-nester species need to lay their eggs in dung pads characterized by a high water content to avoid desiccation, which could hinder larval development. On the other hand, paracoprid and telecoprid dung beetles bury dung under the soil, where water loss is prevented and coarser and drier dung may not affect larval development [80]. However, our results might also be explained by the phenology of the species that prefer horse or cow dung. Indeed, cow dung was clearly preferred by dung beetles that are active throughout the year or in the summer-autumn period, whereas horse dung was selected by species with a phenological peak during autumn, winter and spring. In the region under study, an average annual precipitation of $1000 \mathrm{~mm}$ was recorded with maximum levels in spring and autumn. Hence, non-nester species, such as the Melinopterus and Nimbus species, can exploit horse dung regardless of its lower moisture content because they are at their phenological peak during wet seasons.

Finally, as a caveat, we must recognize that the collection method can influence the results in trophic preference experiments [81]. Indeed, even though pitfall traps make it possible to conduct large-scale controlled experiments, dung beetles cannot escape from such traps, and this method could reflect the pattern of initial colonization by adult beetles (i.e., findability). On the other hand, collecting with dung pats reflects both findability and preference [18].

\section{Conclusions}

We confirmed the presence of species specific dung beetle trophic preferences for horse or cow dung. Moreover, we found differences in the mouthpart traits of dung beetles between these two excrements. The development of the zygum, as well as the percentage of molar and conjunctive areas, appear to play an important role in the community assembly process and dung choice. This could be related to the difference in the moisture and fiber contents of horse and cow excrement, which selected species based on their ability to filtrate and concentrate small particles. Although dung beetles use volatile organic compounds to discriminate between dung types, their choice could also be related to their capacity to make use of a particular excrement type, which may vary according to their mouthpart morphology. Moreover, larger and nester beetles showed a preference for cow dung, whereas smaller and non-nester beetles preferred horse dung. Larger dung beetles probably maximize their fitness by using cow dung. Generally, non-nester species need a more humid and stable resource (such as ruminant dung), but the presence of these species during the wet season could explain their choice of horse dung. Further studies using more dung types are needed to better understand the role of functional traits in dung beetle trophic preferences and consequent community assembly processes.

Supplementary Materials: The following are available online at https://www.mdpi.com/article/ 10.3390/life11090873/s1, Supplementary Material S1: Rationale of selected and measured func-tional traits; Supplementary Material S2: Dung beetles average traits values. Supplementary Material S3: Linear Mixed Model regarding the CWM, FDvar and FRO of dung beetle functional traits in cow and horse dung.

Author Contributions: Conceptualization, M.T., J.R.V. and M.Z.; Methodology, M.T., J.R.V., V.C.G.G. and F.C.; Software, M.T. and F.C.; Validation, M.T., J.R.V., V.C.G.G., F.C. and M.Z.; Formal Analysis, M.T. and F.C.; Investigation, M.T.; Data Curation, M.T., V.C.G.G., J.R.V. and F.C.; Writing-Original Draft Preparation, M.T. and V.C.G.G.; Writing—Review \& Editing, M.T., J.R.V., V.C.G.G., F.C. and M.Z. All authors have read and agreed to the published version of the manuscript.

Funding: This research received no external funding.

Institutional Review Board Statement: Not applicable.

Informed Consent Statement: Not applicable.

Data Availability Statement: The data presented in this study are available in the article. 
Acknowledgments: We wish to thank Timothy Clifford Bloom for his linguistic revision of the manuscript. We also thank three anonymous reviewers for their constructive comments, which helped us to improve the manuscript.

Conflicts of Interest: The authors declare no conflict of interest.

\section{References}

1. Roskov, Y.; Ower, G.; Orrell, T.; Nicolson, D.; Bailly, N.; Kirk, P.M.; Bourgoin, T.; DeWalt, R.E.; Decock, W.; van Nieukerken, E.; et al. P. Scarabs: World Scarabaeidae Database (version Jan 2019). In Species 2000 \& ITIS Catalogue of Life, 2019 Annual Checklist; Species Naturalis: Leiden, The Netherlands, 2019; ISSN 2405-884X; Available online: www.catalogueoflife.org/annual-checklist/2019 (accessed on 2 January 2020).

2. Ahrens, D.; Schwarzer, J.; Vogler, A.P. The evolution of scarab beetles tracks the sequential rise of angiosperms and mammals. Proc. R. Soc. B 2014, 281, 20141470. [CrossRef]

3. Gunter, N.L.; Weir, T.A.; Slipinksi, A.; Bocak, L.; Cameron, S.L. If dung beetles (Scarabaeidae: Scarabaeinae) arose in association with dinosaurs, did they also suffer a mass co-extinction at the K-Pg boundary? PLoS ONE 2016, 11, e0153570. [CrossRef]

4. Schweiger, A.H.; Svenning, J.-C. Down-sizing of dung beetle assemblages over the last 53000 years is consistent with a dominant effect of megafauna losses. Oikos 2018, 127, 1243-1250. [CrossRef]

5. Giménez Gómez, V.C.; Verdú, J.R.; Gómez-Cifuentes, A.; Vaz-de-Mello, F.Z.; Zurita, G.A. Influence of land use on the trophic niche overlap of dung beetles in the semideciduous Atlantic forest of Argentina. Insect Conserv. Divers. 2018, 11, 554-564. [CrossRef]

6. Giménez Gómez, V.C.; Verdú, J.R.; Velazco, S.J.E.; Zurita, G.A. Dung beetle trophic ecology: Are we misunderstanding resources attraction? Ecol. Entomol. 2020, 46, 552-561. [CrossRef]

7. Halffter, G.; Matthews, E.G. The natural history of dung beetles of the Subfamily Scarabaeinae. In Folia Entomológica Mexicana; Carretera, Mexico, D.F., Ed.; 1966; 12-14; p. 312.

8. Hanski, I.; Cambefort, Y. Dung Beetle Ecology; Princeton University Press: Princeton, NJ, USA, $1991 ;$ p. XII + 481.

9. Jones, A.G.; Forgie, S.A.; Scott, D.J.; Beggs, J.R. Generalist dung attraction response in a New Zealand dung beetle that evolved with an absence of mammalian herbivores. Ecol. Entomol. 2012, 37, 124-133. [CrossRef]

10. Frank, K.; Krell, F.T.; Slade, E.M.; Raine, E.H.; Chiew, L.Y.; Schmitt, T.; Vairappan, C.S.; Walter, P.; Blüthgen, N. Global dung webs: High trophic generalism of dung beetles along the latitudinal diversity gradient. Ecol. Lett. 2018, 21, 1229-1236. [CrossRef] [PubMed]

11. Lumaret, J.P.; Iborra, O. Separation of trophic niches by dung beetles (Coleoptera, Scarabaeoidea) in overlapping habitats. Pedobiologia 1996, 40, 392-404.

12. Galante, E.; Cartagena, M.C. Comparison of Mediterranean dung beetles (Coleoptera: Scarabaeoidea) in cattle and rabbit dung. Environ. Entomol. 1999, 28, 420-424. [CrossRef]

13. Larsen, T.H.; Lopera, A.; Forsyth, A. Extreme trophic and habitat specialization by Peruvian dung beetles (Coleoptera: Scarabaeidae: Scarabaeinae). Coleopt. Bull. 2006, 60, 315-324. [CrossRef]

14. Carpaneto, G.M.; Mazziotta, A.; Pittino, R.; Luiselli, L. Exploring co-extinction correlates: The effects of habitat, biogeography and anthropogenic factors on ground squirrels-dung beetles associations. Biodivers. Conserv. 2011, 20, 3059-3076. [CrossRef]

15. Sánchez-Huerta, J.L.; Tonelli, M.; Zunino, M.; Halffter, G. Redescription of Onthophagus halffteri Zunino (Coleoptera: Scarabaeidae: Scarabaeinae) with ecological and distributional notes. Coleopt. Bull. 2015, 69, 225-230. [CrossRef]

16. Martín-Piera, F.; Lobo, J.M. A comparative discussion of trophic preferences in dung beetle communities. Misc. Zool. 1996, 19, 13-31.

17. Finn, J.A.; Giller, P.S. Experimental investigations of colonisation by north temperate dung beetles of different types of domestic herbivore dung. Appl. Soil Ecol. 2002, 20, 1-13. [CrossRef]

18. Dormont, L.; Epinat, G.; Lumaret, J.P. Trophic preferences mediated by olfactory cues in dung beetles colonizing cattle and horse dung. Environ. Entomol. 2004, 33, 370-377. [CrossRef]

19. Errouissi, F.; Haloti, S.; Jay-Robert, P.; Janati-Idrissi, A.; Lumaret, J.P. Effects of the attractiveness for dung beetles of dung pat origin and size along a climatic gradient. Environ. Entomol. 2004, 33, 45-53. [CrossRef]

20. Carpaneto, G.M.; Mazziotta, A.; Ieradi, M. Use of habitat resources by scarab dung beetles in an African savanna. Environ. Entomol. 2010, 39, 1756-1764. [CrossRef]

21. Noriega, J.A. Dung beetles (Coleoptera: Scarabaeinae) attracted to Lagothrix lagotricha (Humboldt) and Alouatta seniculus (Linnaeus) (Primates: Atelidae) dung in a Colombian Amazon forest. Psyche 2012, 2012, 437589. [CrossRef]

22. Puker, A.; Correa, C.M.A.; Korasaki, V.; Ferreira, K.R.; Oliveira, N.G. Dung beetles (Coleoptera: Scarabaeidae) attracted to dung of the largest herbivorous rodent on earth: A comparison with human feces. Environ. Entomol. 2013, 42, 1218-1225. [CrossRef]

23. Bogoni, J.A.; Hernández, M.I.M. Attractiveness of native mammal's feces of different trophic guilds to dung beetles (Coleoptera: Scarabaeinae). J. Insect Sci. 2014, 14, 299. [CrossRef]

24. Frank, K.; Brückner, A.; Hilpert, A.; Heethoff, M.; Blüthgen, N. Nutrient quality of vertebrate dung as a diet for dung beetles. Sci. Rep. 2017, 7, 12141. [CrossRef]

25. Barbero, E.; Palestrini, C.; Rolando, A. Dung beetle conservation: Effects of habitat and resource selection (Coleoptera: Scarabaeoidea). J. Insect Conserv. 1999, 3, 75-84. [CrossRef] 
26. Hanski, I. Nutritional ecology of dung- and carrion-feeding insects. In Nutritional Ecology of Insects, Mites, and Spiders; Slansky, F., Rodriguez, J.G., Eds.; John Wiley \& Sons: New York, NY, USA, 1987; pp. 837-884.

27. Holter, P. Herbivore dung as food for dung beetles: Elementary coprology for entomologists. Ecol. Entomol. 2016, 41, 367-377. [CrossRef]

28. Chame, M. Terrestrial mammal feces: A morphometric summary and description. Mem. Inst. Oswaldo Cruz 2003, 98 (Suppl. I), 71-94. [CrossRef]

29. Dormont, L.; Jay-Robert, P.; Bessière, J.M.; Rapior, S.; Lumaret, J.P. Innate olfactory preferences in dung beetles. J. Exp. Biol. 2010, 213, 3177-3186. [CrossRef] [PubMed]

30. Stavert, J.R.; Gaskett, A.C.; Scott, D.J.; Beggs, J.R. Dung beetles in an avian-dominated island ecosystem: Feeding and trophic ecology. Oecologia 2014, 176, 259-271. [CrossRef]

31. Frank, K.; Brückner, A.; Blüthgen, N.; Schmitt, T. In search of cues: Dung beetle attraction and the significance of volatile composition of dung. Chemoecology 2018, 28, 145-152. [CrossRef]

32. Inouchi, J.; Shibuya, T.; Hatanaka, T. Food odor responses of single antennal olfactory cells in the Japanese dung beetle, Geotrupes auratus (Coleoptera: Geotrupidae). Appl. Entomol. Zool. 1988, 23, 167-174. [CrossRef]

33. Wurmitzer, C.; Blüthgen, N.; Krel, F.T.; Maldonado, B.; Ocampo, F.; Müller, J.K.; Schmitt, T. Attraction of dung beetles to herbivore dung synthetic compounds in a comparative field study. Chemoecology 2017, 27, 75-84. [CrossRef]

34. Hunt, J.; Simmons, L.W. Optimal maternal investment in the dung beetle Onthophagus taurus? Behav. Ecol. Sociobiol. 2004, 55, 302-312. [CrossRef]

35. Arellano, L.; Castillo-Guevara, C.; Huerta, C.; Germán-García, A.; Lara, C. Effect of using different types of animal dung for feeding and nesting by the dung beetle Onthophagus lecontei (Coleoptera: Scarabaeinae). Can. J. Zool. 2015, 93, 337-343. [CrossRef]

36. Lumaret, J.P.; Kadiri, N.; Bertrand, M. Changes in resources: Consequences for the dynamics of dung beetle communities. J. Appl. Ecol. 1992, 29, 349-356. [CrossRef]

37. Carpaneto, G.M.; Mazziotta, A.; Piattella, E. Changes in food resources and conservation of scarab beetles: From sheep to dog dung in a green urban area of Rome (Coleoptera, Scarabaeoidea). Biol. Conserv. 2005, 123, 547-556. [CrossRef]

38. Tonelli, M.; Verdú, J.R.; Zunino, M. Effects of the progressive abandonment of grazing on dung beetle biodiversity: Body size matters. Biodivers. Conserv. 2018, 27, 189-204. [CrossRef]

39. Tonelli, M.; Verdú, J.R.; Zunino, M. Grazing abandonment and dung beetle assemblage composition: Reproductive behaviour has something to say. Ecol. Indic. 2019, 96, 361-367. [CrossRef]

40. Gittings, T.; Giller, P.S. Resource quality and the colonization and succession of coprophagous dung beetles. Ecography 1998, 21, 581-592. [CrossRef]

41. Bürgis, H. Gourmets unter den Käfern: Die kotfresser (Coprophaga). I. Hartkotfresser vom Geotrupes-Typ. A. Lebensweise und mundwerkzeuge des Stierkäfers. Mikrokosmos 1982, 71, 298-303.

42. Bürgis, H. Gourmets unter den Käfern: Die kotfresser (Coprophaga). I. Hartkotfresser vom Geotrupes-Typ. B. Nahrungsaufnahme der Hartkotfresser. Mikrokosmos 1982, 71, 341-344.

43. Bürgis, H. Gourmets unter den Käfern: Die kotfresser (Coprophaga). II. Weichkotfresser vom Aphodius-Typ. A. Lebensweise und mundwerkzeuge des Mondhornkäfers. Mikrokosmos 1984, 73, 45-50.

44. Bürgis, H. Gourmets unter den Käfern: Die kotfresser (Coprophaga). II. Weichkotfresser vom Aphodius-Typ. B. Die nahrungsaufnahme der adulten Weichkotfresser. Mikrokosmos 1984, 73, 368-374.

45. Nock, C.A.; Vogt, R.J.; Beisner, B.E. Functional Traits. In ELS; John Wiley \& Sons, Ltd.: Chichester, UK, 2016; pp. 1-8. [CrossRef]

46. Spasojevic, M.J.; Suding, K.N. Inferring community assembly mechanisms from functional diversity patterns: The importance of multiple assembly processes. J. Ecol. 2012, 100, 652-661. [CrossRef]

47. Kraft, N.J.B.; Adler, P.B.; Godoy, O.; James, E.C.; Fuller, S.; Levine, J.M. Community assembly, coexistence and the environmental filtering metaphor. Funct. Ecol. 2015, 29, 592-599. [CrossRef]

48. Violle, C.; Navas, M.-L.; Vile, D.; Kazakou, E.; Fortunel, C.; Hummel, I.; Garnier, E. Let the concept of trait be functional. Oikos 2007, 116, 882-892. [CrossRef]

49. Fountain-Jones, N.; Baker, S.C.; Jordan, G.J. Moving beyond the guild concept: Developing a practical functional trait framework for terrestrial beetles. Ecol. Entomol. 2015, 40, 1-13. [CrossRef]

50. Milotić, T.; Baltzinger, C.; Eichberg, C.; Eycott, A.E.; Heurich, M.; Müller, J.; Noriega, J.A.; Menendez, R.; Stadler, J.; Ádám, R.; et al. Functionally richer communities improve ecosystem functioning: Dung removal and secondary seed dispersal by dung beetles in the Western Palearctic. J. Biogeogr. 2019, 46, 70-82. [CrossRef]

51. Tonelli, M.; Verdú, J.R.; Zunino, M. Effects of grazing intensity and the use of veterinary medical products on dung beetle biodiversity in the sub-mountainous landscape of Central Italy. PeerJ 2017, 5, e2780. [CrossRef]

52. Larsen, T.H.; Forsyth, A. Trap spacing and transect design for dung beetle biodiversity studies. Biotropica 2005, 37, 322-325. [CrossRef]

53. Silva, P.G.D.; Hernández, M.I.M. Spatial patterns of movement of dung beetle species in a tropical forest suggest a new trap spacing for dung beetle biodiversity studies. PLoS ONE 2015, 10, e0126112. [CrossRef] [PubMed]

54. Lobo, J.M.; Martín-Piera, F.; Veiga, C.M. Las trampas pitfall con cebo, sus posibilidades en el estudio de las comunidades coprófagas de Scarabaeoidea (Col.): I. Características determinantes de su capacidad de captura. Rev. D'écologie Biol. Sol 1988, 25, 77-100. 
55. Errouissi, F; Lumaret, J.P. Field effects of faecal residues from ivermectin slow-release boluses on the attractiveness of cattle dung to dung beetles. Med Vet. Entomol. 2010, 24, 433-440. [CrossRef]

56. Tonelli, M.; Verdú, J.R.; Morelli, F.; Zunino, M. Dung beetles: Functional identity, not functional diversity, accounts for ecological process disruption caused by the use of veterinary medical products. J. Insect Conserv. 2020, 24, 643-654. [CrossRef]

57. Dufrêne, M.; Legendre, P. Species assemblages and indicator species: The need for a flexible asymmetrical approach. Ecol. Monogr. 1997, 67, 345-366. [CrossRef]

58. McCune, B.; Mefford, M.J. PC-ORD Multivariate Analysis of Ecological Data, Version 4.0; MjM Software: Gleneden Beach, OR, USA, 1999.

59. Garnier, E.; Cortez, J.; Billès, G.; Navas, M.L.; Roumet, C.; Debussche, M.; Laurent, G.; Blanchard, A.; Aubry, D.; Bellmann, A.; et al. Plant functional markers capture ecosystem properties during secondary succession. Ecology 2004, 85, 2630-2637. [CrossRef]

60. Mason, N.W.H.; MacGillivray, K.; Steel, J.B.; Wilson, J.B. An index of functional diversity. J. Veg. Sci. 2003, 14, 571-578. [CrossRef]

61. Mason, N.W.H.; Mouillot, D.; Lee, W.G.; Wilson, J.B. Functional richness, functional evenness and functional divergence: The primary components of functional diversity. Oikos 2005, 111, 112-118. [CrossRef]

62. Mouillot, D.; Mason, N.W.H.; Dumay, O.; Wilson, J.B. Functional regularity: A neglected aspect of functional diversity. Oecologia 2005, 142, 353-359. [CrossRef]

63. Casanoves, F.; Pla, L.; Di Rienzo, J.A.; Díaz, S. FDiversity: A software package for the integrated analysis of functional diversity. Methods Ecol. Evol. 2011, 2, 233-237. [CrossRef]

64. Di Rienzo, J.A.; Macchiavelli, R.E.; Casanoves, F. Modelos Lineales Mixtos: Aplicaciones en InfoStat, 1st ed.; Grupo InfoStat: Córdoba, Argentina, 2011; p. 193.

65. Di Rienzo, J.A.; Casanoves, F.; Balzarini, M.G.; Gonzalez, L.; Tablada, M.; Robledo, C.W. InfoStat Version 2020. Centro de Transferencia InfoStat, FCA, Universidad Nacional de Córdoba, Argentina. 2020. Available online: http://www.infostat.com.ar (accessed on 2 January 2020).

66. Dormont, L.; Rapior, S.; McKey, D.B.; Lumaret, J.P. Influence of dung volatiles on the process of resource selection by coprophagous beetles. Chemoecology 2007, 17, 23-30. [CrossRef]

67. Dellacasa, G.; Dellacasa, M. Coleoptera Aphodiidae, Aphodiinae; Fauna d'Italia, Coleoptera Aphodiidae Aphodiinae; Calderini de Il Sole 24 Ore.: Milano, Italia, 2006; Volume XLI, p. 484.

68. Lumaret, J.P. Atlas Des Coléoptères Scarabéides Laparosticti de France; Muséum National d'Histoire Naturelle; Secrétariat de la Faune et la Flore: Paris, France, 1990; p. 419.

69. Verdú, J.R.; Galante, E. Behavioural and morphological adaptations for a low-quality resource in semi-arid environments: Dung beetles (Coleoptera, Scarabaeoidea) associated with the European rabbit (Oryctolagus cuniculus L.). J. Nat. Hist. 2004, 38, 705-715. [CrossRef]

70. Dellacasa, G.; Dellacasa, M.; Mann, D.J. The Morphology of the Labrum (Epipharynx, Ikrioma and Aboral Surface) of Adult Aphodiini (Coleoptera: Scarabaeidae: Aphodiinae), and Its Implications for Systematics. Insecta Mundi 2010, $132,1-21$.

71. Holter, P.; Scholtz, C.H. Re-establishment of biting mouthparts in desert-living dung beetles (Scarabaeidae: Scarabaeinae) feeding on plant litter-old structures reacquired or new ones evolved? J. Morphol. 2011, 272, 1007-1016. [CrossRef]

72. Hata, K.; Edmonds, W.D. Structure and function of the mandibles of adult dung beetles (Coleoptera: Scarabaeidae). Int. J. Insect Morphol. Embryol. 1983, 12, 1-12. [CrossRef]

73. Holter, P. Particle feeding in Aphodius dung beetles (Scarabaeidae): Old hypotheses and new experimental evidence. Funct. Ecol. 2000, 14, 631-637. [CrossRef]

74. Scholtz, C.H.; Davis, A.L.V.; Kryger, U. Evolutionary Biology and Conservation of Dung Beetles; Pensoft Publishers: Sofia, Bulgaria, $2009 ;$ p. 567.

75. Moczek, A.P. Horn polyphenism in the beetle Onthophagus taurus: Larval diet quality and plasticity in parental investment determine adult body size and male horn morphology. Behav. Ecol. 1998, 9, 636-641. [CrossRef]

76. Kishi, S.; Nishida, T. Adjustment of parental investment in the dung beetle Onthophagus atripennis (Col. Scarabaeidae). Ethology 2006, 112, 1239-1245. [CrossRef]

77. Edwards, P.B. Seasonal variation in the dung of African grazing mammals, and its consequences for coprophagous insects. Funct. Ecol. 1991, 5, 617-628. [CrossRef]

78. Tonelli, M. Some considerations on the terminology applied to dung beetle functional groups. Ecol. Entomol. 2021, 46, 772-776. [CrossRef]

79. Milotić, T.; Quidé, S.; Van Loo, T.; Hoffmann, M. Linking functional group richness and ecosystem functions of dung beetles: An experimental quantification. Oecologia 2017, 183, 177-190. [CrossRef]

80. Tocco, C.; Balmer, J.P.; Villet, M.H. Trophic preference of southern African dung beetles (Scarabaeoidea: Scarabaeinae and Aphodiinae) and its influence on bioindicator surveys. Afr. J. Ecol. 2018, 56, 938-948. [CrossRef]

81. Kadlec, J.; Mikatova, S.; Maslo, P.; Sipkova, H.; Sipek, P.; Sladecek, F.X.J. Delaying insect access alters community composition on small carrion: A quantitative approach. Entomol. Exp. Appl. 2019, 167, 729-740. [CrossRef] 